Prepared in cooperation with the Platte River Recovery Implementation Program

\title{
River Channel Topographic Surveys Collected Prior to and Following Elevated Flows in the Central Platte River, Spring 2008
}

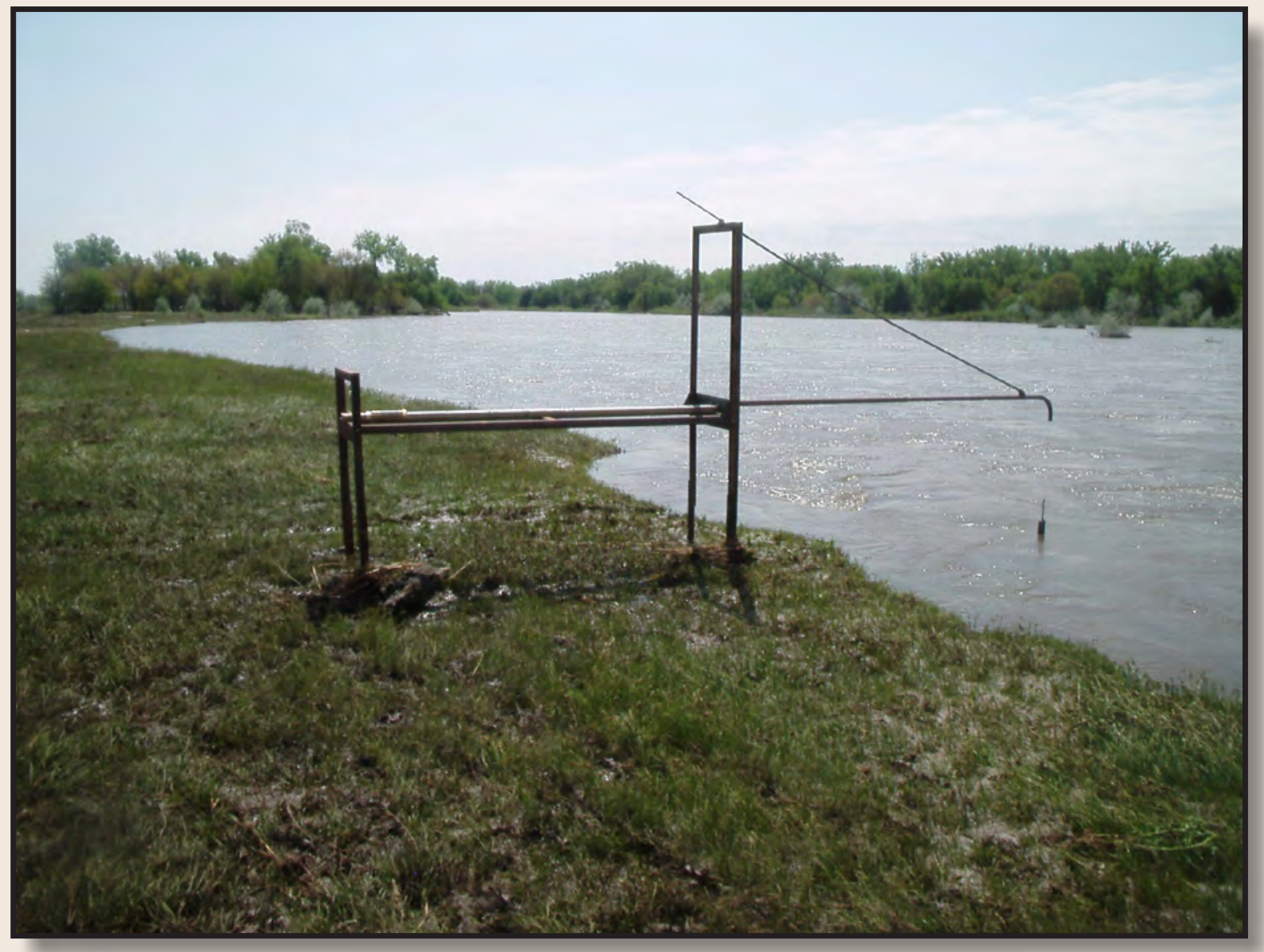

Data Series 380 
COVER: Photograph taken May 22, 2008, of the cantilever gage at the Output Reach in the Cottonwood Ranch study area. Image courtesy of John Miller. 


\section{River Channel Topographic Surveys Collected Prior to and Following Elevated Flows in the Central Platte River, Nebraska, Spring 2008}

By Paul J. Kinzel

Prepared in cooperation with the Platte River Recovery Implementation Program

Data Series 380 


\section{U.S. Department of the Interior DIRK KEMPTHORNE, Secretary}

\section{U.S. Geological Survey \\ Mark D. Myers, Director}

\section{U.S. Geological Survey, Reston, Virginia: 2008}

For product and ordering information:

World Wide Web: http://www.usgs.gov/pubprod

Telephone: 1-888-ASK-USGS

For more information on the USGS — the Federal source for science about the Earth, its natural and living resources, natural hazards, and the environment:

World Wide Web: http://www.usgs.gov

Telephone: 1-888-ASK-USGS

Any use of trade, product, or firm names is for descriptive purposes only and does not imply endorsement by the U.S. Government.

Although this report is in the public domain, permission must be secured from the individual copyright owners to reproduce any copyrighted materials contained within this report.

Suggested citation:

Kinzel, P.J., 2008, River channel topographic surveys collected prior to and following elevated flows in the central Platte River, Nebraska, spring 2008: U.S. Geological Survey Data Series 380, 10 p. 


\section{Contents}

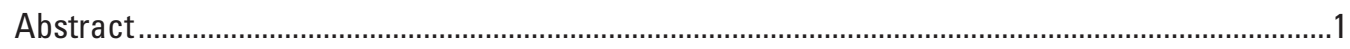

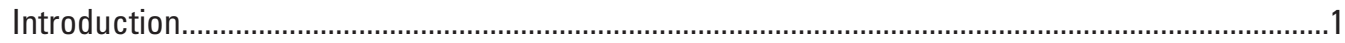

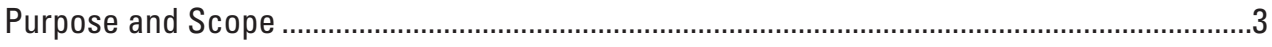

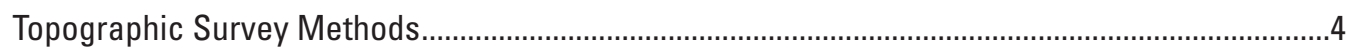

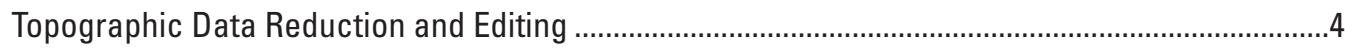

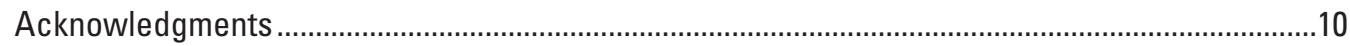

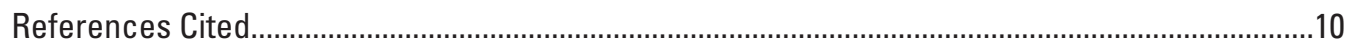

\section{Figures}

1. Hydrographs of provisional minimum, maximum, and mean daily streamflows measured at various USGS streamflow-gaging stations along the Platte River between May 1, 2008, and July 1, 2008

2. Map of the central Platte River showing the location of the study areas and USGS streamflow-gaging stations.

3. Map showing the location of the Cottonwood Ranch Property study area, study reaches, and USGS streamflow-gaging stations 06768000, Platte River near Overton, Nebr., and 06768035, Platte River Middle Channel at Cottonwood Ranch near Elm Creek, Nebr.

4. Aerial color infrared photograph of reaches in the Cottonwood Ranch study area taken June 22, 2008, showing the location of geomorphic monitoring transects

5. Aerial color infrared photograph of the Rowe Sanctuary study area taken June 22, 2008, showing the location of geomorphic monitoring transects.

6. Aerial color infrared photograph of the Uridil study area taken June 22, 2008, showing the location of geomorphic monitoring transects and the USGS stage gage 06770375, Platte River near Prosser, Nebr.

\section{Table}

1. Topographic survey dates. 


\section{Conversion Factors}

Inch/Pound to SI

\begin{tabular}{lcl}
\hline Multiply & By & To obtain \\
\hline inch (in.) & Length & \\
inch (in.) & 2.54 & centimeter $(\mathrm{cm})$ \\
foot (ft) & 25.4 & millimeter $(\mathrm{mm})$ \\
mile (mi) & 0.3048 & meter $(\mathrm{m})$ \\
& 1.609 & kilometer $(\mathrm{km})$ \\
\hline acre & Area & \\
acre & 4,047 & square meter $\left(\mathrm{m}^{2}\right)$ \\
acre & 0.4047 & hectare $($ ha) \\
acre & 0.4047 & square hectometer $\left(\mathrm{hm}^{2}\right)$ \\
& 0.004047 & square kilometer $\left(\mathrm{km}^{2}\right)$ \\
\hline acre-foot (acre-ft) & Volume & \\
acre-foot (acre-ft) & 1,233 & cubic meter $\left(\mathrm{m}^{3}\right)$ \\
& 0.001233 & cubic hectometer $\left(\mathrm{hm}^{3}\right)$ \\
\hline cubic foot per second $\left(\mathrm{ft}^{3} / \mathrm{s}\right)$ & Flow rate & \\
\hline
\end{tabular}

Vertical coordinate information is referenced to the North American Vertical Datum of 1988 (NAVD 88).

Horizontal coordinate information is referenced to the North American Datum of 1983 (NAD 83). 


\title{
River Channel Topographic Surveys Collected Prior to and Following Elevated Flows in the Central Platte River, Nebraska, Spring 2008
}

\author{
By Paul J. Kinzel
}

\begin{abstract}
Rainfall in central Nebraska in late May and early June 2008 elevated streamflows in the central Platte River. Topographic surveys collected along geomorphic monitoring transects prior to these flows (May 2007, July 2007, and March 2008) were repeated in mid-June 2008. These surveys provide characterization of river topography that could be used (1) to infer changes in channel morphology that occurred as a result of this flow event, and (2) to aide in the determination of the effect of managed and natural flow events on habitats for endangered and threatened species in the Platte River basin. The primary purposes of this report are to summarize the methods of data collection, processing, and editing and to make the data described in the report publically available.
\end{abstract}

\section{Introduction}

The Platte River in central Nebraska intersects the North American Central Flyway, an important migratory route for millions of waterbirds. The relatively wide, braided reaches of the Platte River function as attractive stopover habitat for these waterbirds, including the endangered whooping crane (Grus americana), which roosts on submerged sandbars in the river; the endangered interior least tern (Sterna antillarum), which nests on exposed sandbars; and the threatened piping plover (Charadrius melodus), which also nests on exposed sandbars (National Research Council, 2005). Beginning in the 1800s and continuing through the present, water resource development and associated flow regulation in the basin have affected seasonal river hydrographs (Williams, 1978). In response to the altered streamflows, vegetation has encroached (Johnson, 1997), reducing active channel widths for roosting birds. Changes in river hydrographs are also believed to have affected the geomorphic process necessary to provide habitat for the aforementioned nesting birds (National Research Council, 2005).

River managers concerned for the endangered and threatened species are moving toward implementing strategies to modify streamflows in the central Platte River (U.S. Department of Interior, 2006a). One strategy discussed to augment flows is the release of Environmental Account (EA) water. The water in the EA is stored in Lake McConaughy and is managed by the U.S. Fish and Wildlife Service. Each year the EA receives 10 percent of the storable inflows to Lake McConaughy from October through April with a maximum of 100,000 acre-feet in a year; water not released from the EA in one year can be carried over to the next but a limit of 200,000 acre-feet cannot be exceeded (U.S. Department of Interior, 2006b). Managed releases from the EA in the form of pulse flows are intended to improve habitat conditions by increasing sandbar height and reducing the quantity of vegetation in the active channel (U.S. Department of Interior, 2006a). Because pulse flows were not implemented in the spring of 2008, a geomorphic monitoring program was not put into place by the Platte River Recovery Implementation Program to evaluate the effects of these managed flows.

However, storms in central Nebraska between May 22 and 24, 2008, produced between approximately 1 and $4 \mathrm{in}$. of rainfall at the stations in the Central Platte Natural Resources District (information obtained through the Nebraska Rainfall Assessment and Information Network (NeRAIN) website, http://dnrdata.dnr.ne.gov/NeRAIN/index.asp, sponsored by the Nebraska Natural Resources Districts and the Nebraska Department of Natural Resources). The runoff from these precipitation events and other events in early June elevated streamflows in the reach of the Platte River between Overton and Grand Island, Nebr. The maximum provisional streamflows measured at the U.S. Geological Survey (USGS) streamflow-gaging stations at Overton, the Middle Channel at Cottonwood Ranch, Kearney, and Grand Island were $10,400 \mathrm{ft}^{3} / \mathrm{s} ; 7,060 \mathrm{ft}^{3} / \mathrm{s} ; 13,300 \mathrm{ft}^{3} / \mathrm{s} ;$ and $12,700 \mathrm{ft}^{3} / \mathrm{s}$ (fig. 1). These magnitudes had not been observed since 1999 at the streamflow-gaging stations at Overton and Kearney and since 1995 at the streamflow-gaging station at Grand Island, and the discharge measured at the Cottonwood Ranch gage was the highest since installation in 2001 (U.S. Geological Survey, 2008). The magnitude of these natural high flows following a period of record low streamflows from 2000 to 2007 generated interest from the Platte River Recovery Implementation Program in collecting data that could be used to evaluate the effects of elevated flows on the shape of the river channel. 

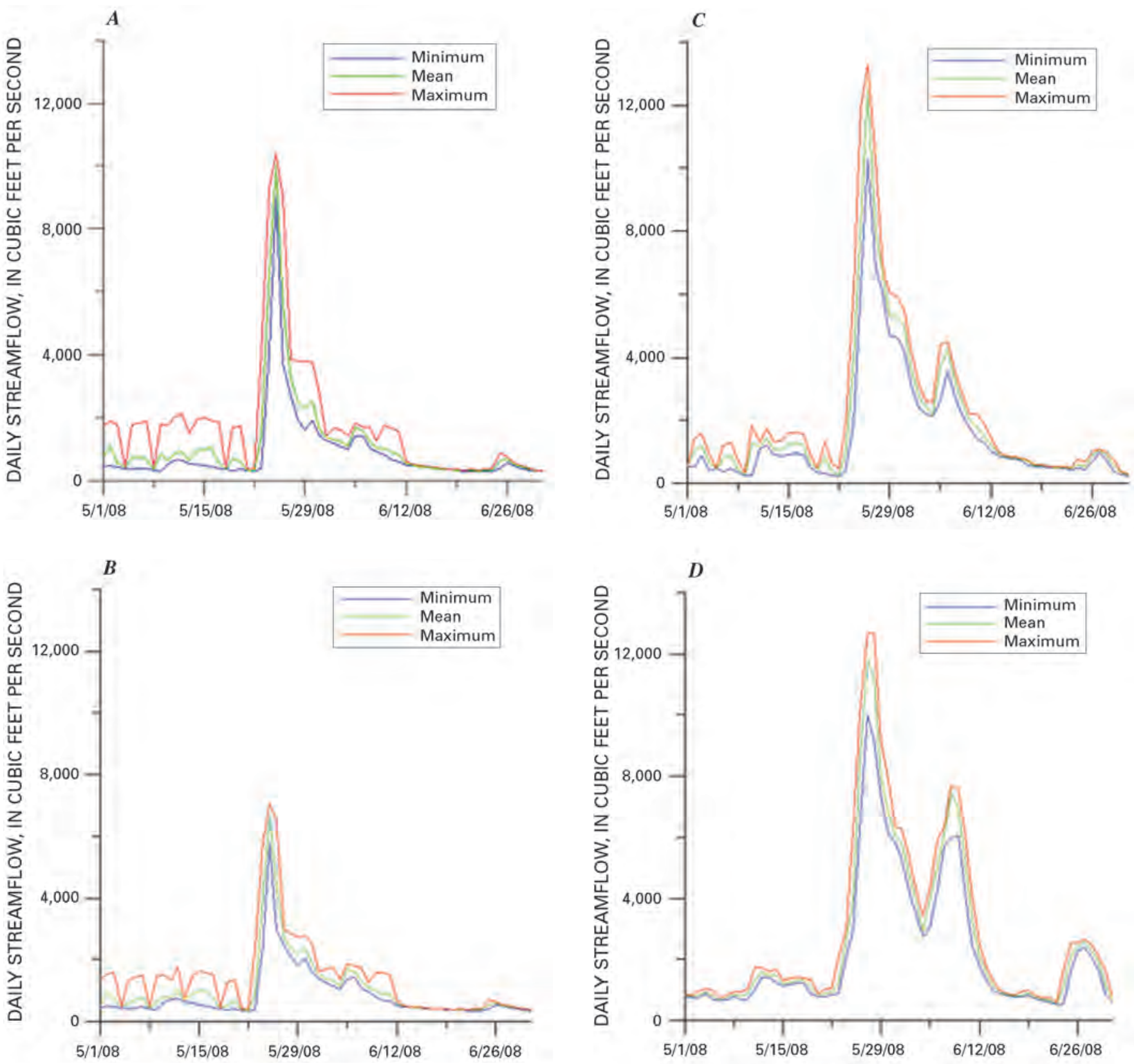

Figure 1. Hydrographs of provisional minimum, maximum, and mean daily streamflows measured at various USGS streamflow-gaging stations along the Platte River between May 1, 2008, and July 1, 2008. A, USGS streamflow-gaging station 06768000, Platte River near Overton, Nebr. B, USGS streamflow-gaging station 06768035, Platte River Middle Channel at Cottonwood Ranch near Elm Creek, Nebr. C, USGS streamflow-gaging station 06770200, Platte River near Kearney, Nebr. D, USGS streamflow-gaging station 06770500, Platte River near Grand Island, Nebr.

Geomorphic monitoring transects have been periodically measured by the USGS since 2000 in support of research related to the USGS Platte River Priority Ecosystem Program (http://ne.water.usgs.gov/platte/index.html), activities related to the Platte River Cooperative Agreement (U.S. Department of Interior, 1997), and a Nebraska Environmental Trust project. Specifically, transects were used (1) to monitor the geomorphic effects of vegetation clearing (Kinzel and others, 2006) and sediment augmentation (Platte River Whooping Crane Maintenance Trust, 2003), (2) to evaluate an experimental airborne light detection and ranging system (Kinzel and others, 2007), and (3) to investigate sandhill crane roosting habitat (Kinzel and others, 2008). The geomorphic monitoring transects are located in three study areas along the central Platte River: the Cottonwood Ranch, the Rowe Sanctuary, and the Uridil properties (fig. 2) were surveyed in June 2008 by the USGS in cooperation with the Platte River Recovery Implementation Program and Nebraska Environmental Trust to compare to surveys collected in May 2007, July 2007, or March 2008. 
The Cottonwood Ranch Property is a 2,650-acre parcel of land located between the Overton and Elm Creek bridges, which cross over the Platte River (fig. 3). The property was purchased by the Nebraska Public Power District in 1992 and has been managed to enhance habitat for endangered and threatened species. As part of a study to monitor the effects of vegetation management on sediment transport and river morphology, the USGS established three study reaches located along the middle channel of the Platte River. The reaches were located upstream from, within, and downstream from the management activities (Kinzel and others, 2006). These study reaches are referred to as the Cottonwood Ranch Input Reach (fig. $4 A$ ), the Cottonwood Ranch Managed Reach (fig. 4B), and the Cottonwood Ranch Output Reach (fig. 4C). A streamflow-gaging station, USGS 06768035, installed in the Output Reach in 2001, measures the streamflow in the middle channel at the downstream end of the Cottonwood Ranch Property (fig. 4C). Eleven monitoring sections in the Cottonwood Ranch Input Reach, 3 in the Cottonwood Ranch Managed Reach, and 25 in the Cottonwood Ranch Output Reach were surveyed in March and June 2008.

The Rowe Sanctuary, owned and managed by the National Audubon Society, includes 1,448 acres of land between the Minden and Gibbon bridges over the Platte River. The property includes holdings adjacent to the river channel, in wet meadow habitats, and in agricultural fields. This area is a popular location for roosting sandhill and whooping cranes and is disced every fall to prevent vegetation establishment on sandbars. In 2000, the USGS initiated a study to examine the effect of river stage and channel shape on the roosting patterns of sandhill cranes. Twenty-two river sections have been periodically resurveyed in the Rowe Sanctuary (fig. 5). These 22 sections were surveyed in July 2007 and again in June 2008.

The Uridil Property, owned by the Platte River Whooping Crane Maintenance Trust, lies along a channel of the Platte River bordered by the Shelton Bridge on the west and the Wood River Bridge on the east. This property is also managed by discing each fall to enhance habitat conditions for migratory birds. In 2005, 30 river transects were established to monitor the fate and transport of sediment introduced into the river channel from a small-scale sediment augmentation project (Platte River Whooping Crane Maintenance Trust, 2003). In May 2007 all 30 transects were surveyed in this reach; however, in June 2008 only the first 18 of these sections were resurveyed because of a change in landowner permissions for surveying access at the downstream end of the study reach (fig. 6).

\section{Purpose and Scope}

This data report provides topographic surveys collected along geomorphic monitoring transects at three study areas along the central Platte River prior to and following elevated flows occurring in the spring (late May and early June) of 2008 (table 1). The surveys are provided in two Microsoft Excel spreadsheets, data before and after the high magnitude flows, respectively: USGS_PLATTE_XS_PRE_5_08.xls; and USGS_PLATTE_XS_POST_5_08.xls. The data presented in this report was collected to characterize river topography and thus aid the determination of the effect of managed and natural flow events on habitats for endangered and threatened species in the Platte River basin.
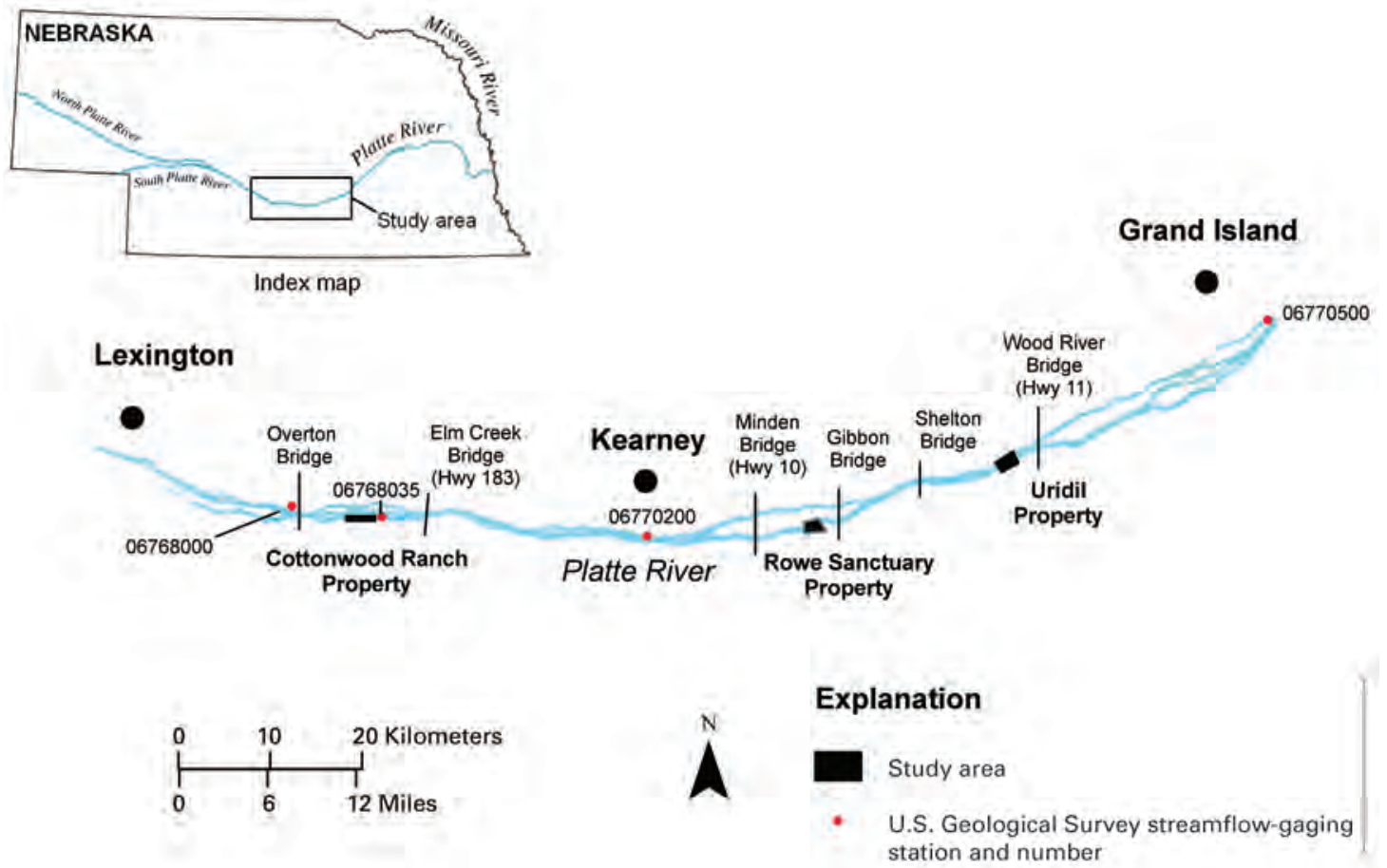

Figure 2. Map of the central Platte River showing the location of the study areas and USGS streamflowgaging stations. 


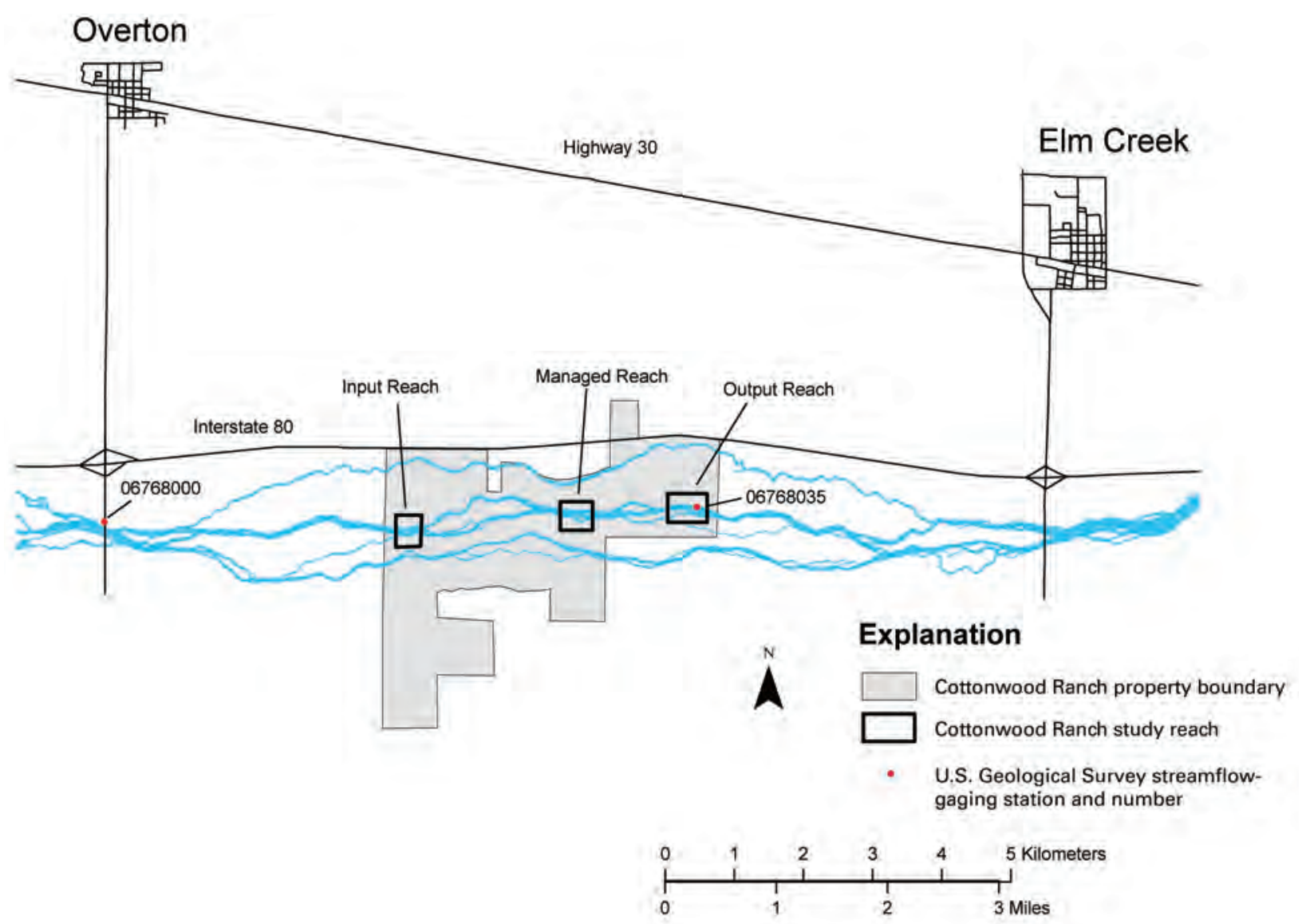

Figure 3. Map showing the location of the Cottonwood Ranch Property study area, study reaches, and USGS streamflowgaging stations 06768000, Platte River near Overton, Nebr., and 06768035, Platte River Middle Channel at Cottonwood Ranch near Elm Creek, Nebr.

\section{Topographic Survey Methods}

Topographic surveying was done to determine the elevation and coordinate locations of geomorphic features within the river channel using a survey-grade global positioning system (GPS). The GPS equipment was operated in a real-time kinematic mode (RTK-GPS); horizontal and vertical precisions for topographic data point collected from an RTK-GPS survey are $\pm 1 \mathrm{~cm}$ and $\pm 2 \mathrm{~cm}$, respectively (Trimble Navigation Limited, 1998). The RTK-GPS equipment included one stationary GPS receiver (base station) positioned over a known location (benchmark), three roving GPS receivers (rovers) each storing GPS locations in separate hand-held computers (data collectors), and a radio to transmit data from the base station to the rovers. The RTK-GPS system calculates the locations of the rovers in real time, using the positions of orbiting NAVSTAR-GPS satellites and the known location of the base station, allowing each surveyor to wade across the river channel along a transect line from one end point to the other corresponding end point. Each transect line was located approximately orthogonal to the main flow direction, marked by wooden stakes in the field. The surveyors collected GPS locations (1) where the water surface met the land surface (that is, at the river bank, at a sandbar, or an island); (2) at breaks in elevation (that is, the top and bottom of the river bank); and (3) at regular intervals if the terrain was relatively flat (at least every few meters).

\section{Topographic Data Reduction and Editing}

The topographic survey data stored in the GPS rover data collectors was downloaded to a personal computer for evaluation and editing. The survey data was output to a spreadsheet program in metric Northing, Easting, and Elevation format using a Universal Transverse Mercator (UTM) coordinate system. Horizontal coordinate information was referenced to the North American Horizontal Datum of 1983 (NAD 83). Vertical coordinate information was referenced to the North American Vertical Datum of 1988 (NAVD 88) by using the geoid model for the conterminous United States (Geoid 99 (Conus)) (Smith and Roman, 2001). Data were reduced so as to provide a separate spreadsheet worksheet for each study area. Within the study area worksheet each transect was placed in separate columns. Elevation values were visually examined for relative accuracy by graphing and inspecting transects. Codes assigned to topographic data points along transects were checked and edited to ensure consistency of use among surveyors. 


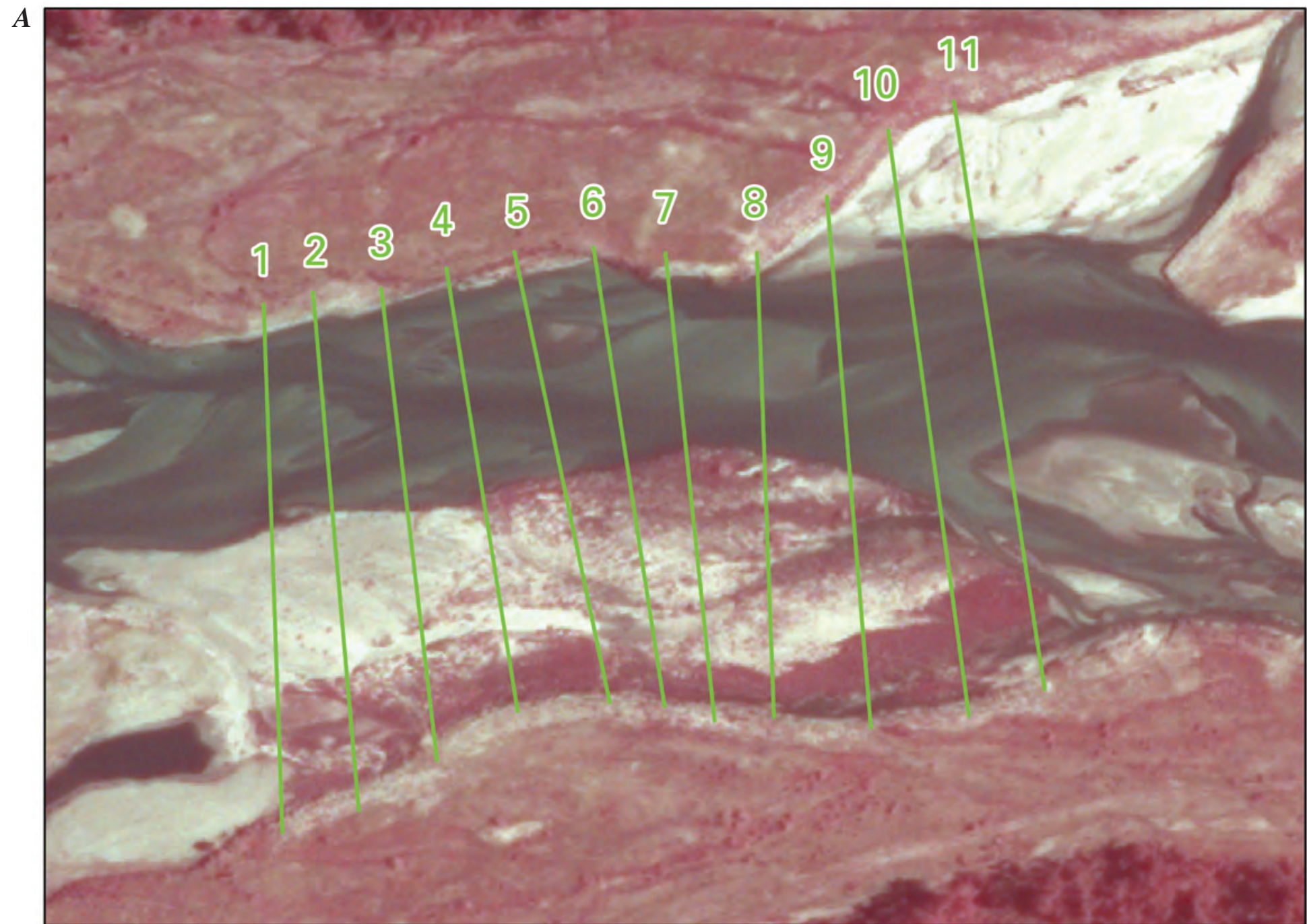

\section{EXPLANATION}

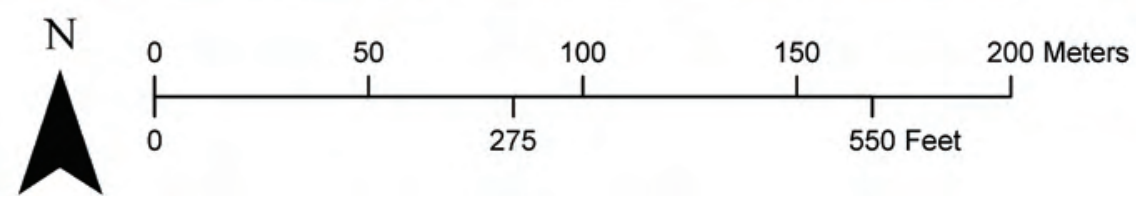

Figure 4. Aerial color infrared photograph of reaches in the Cottonwood Ranch study area taken June 22, 2008, showing the location of geomorphic monitoring transects. Flow is from left to right. $A$, Photograph of the Input Reach. $B$, Photograph of the Managed Reach. $C$, Photograph of the Output Reach. This photograph also shows USGS streamflow-gaging station 06768035, Platte River Middle Channel at Cottonwood Ranch near Elm Creek, Nebr. (Continued on following pages.) 


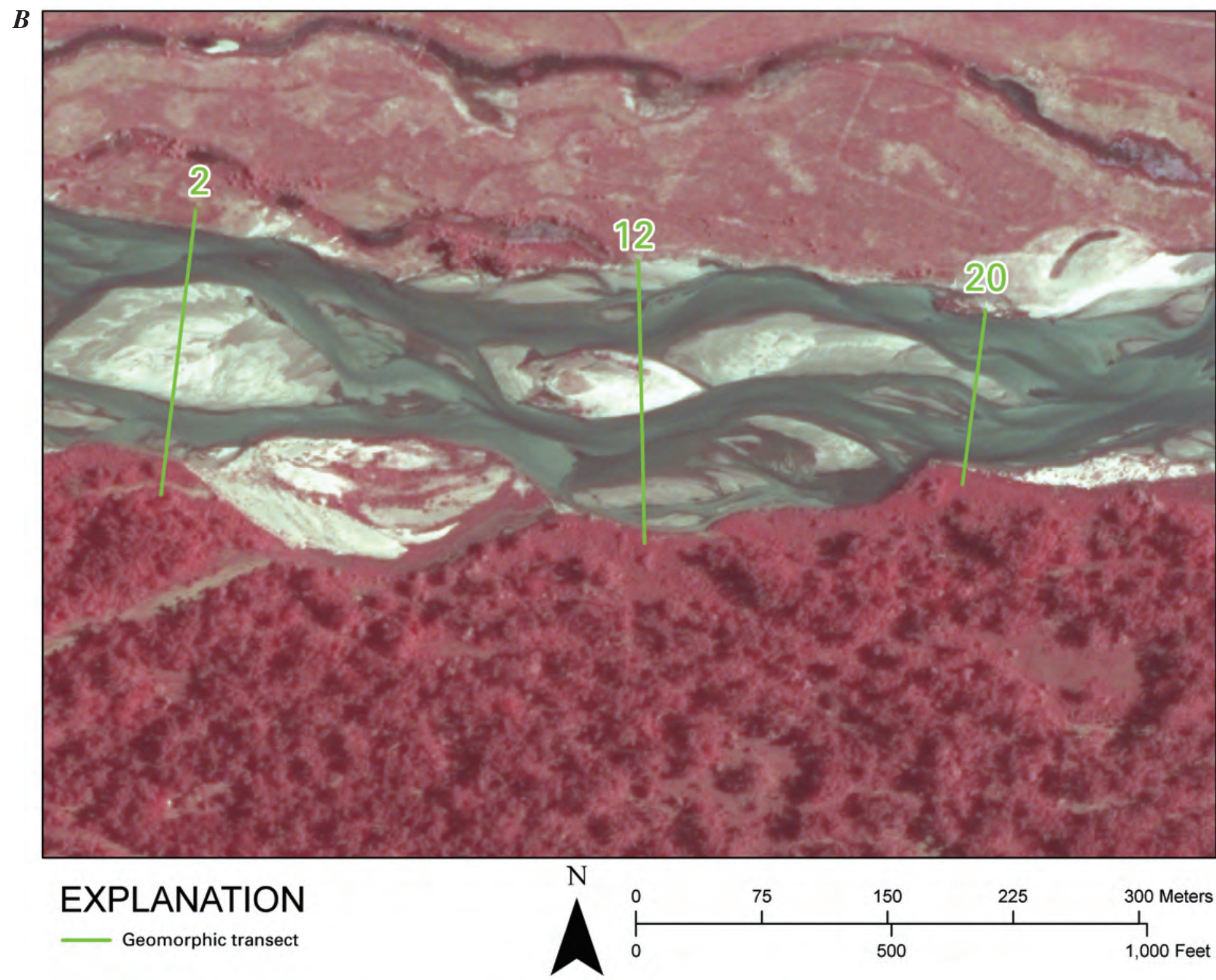

Figure 4-Continued. Aerial color infrared photograph of reaches in the Cottonwood Ranch study area taken June 22, 2008, showing the location of geomorphic monitoring transects. Flow is from left to right. $B$, Photograph of the Managed Reach. 


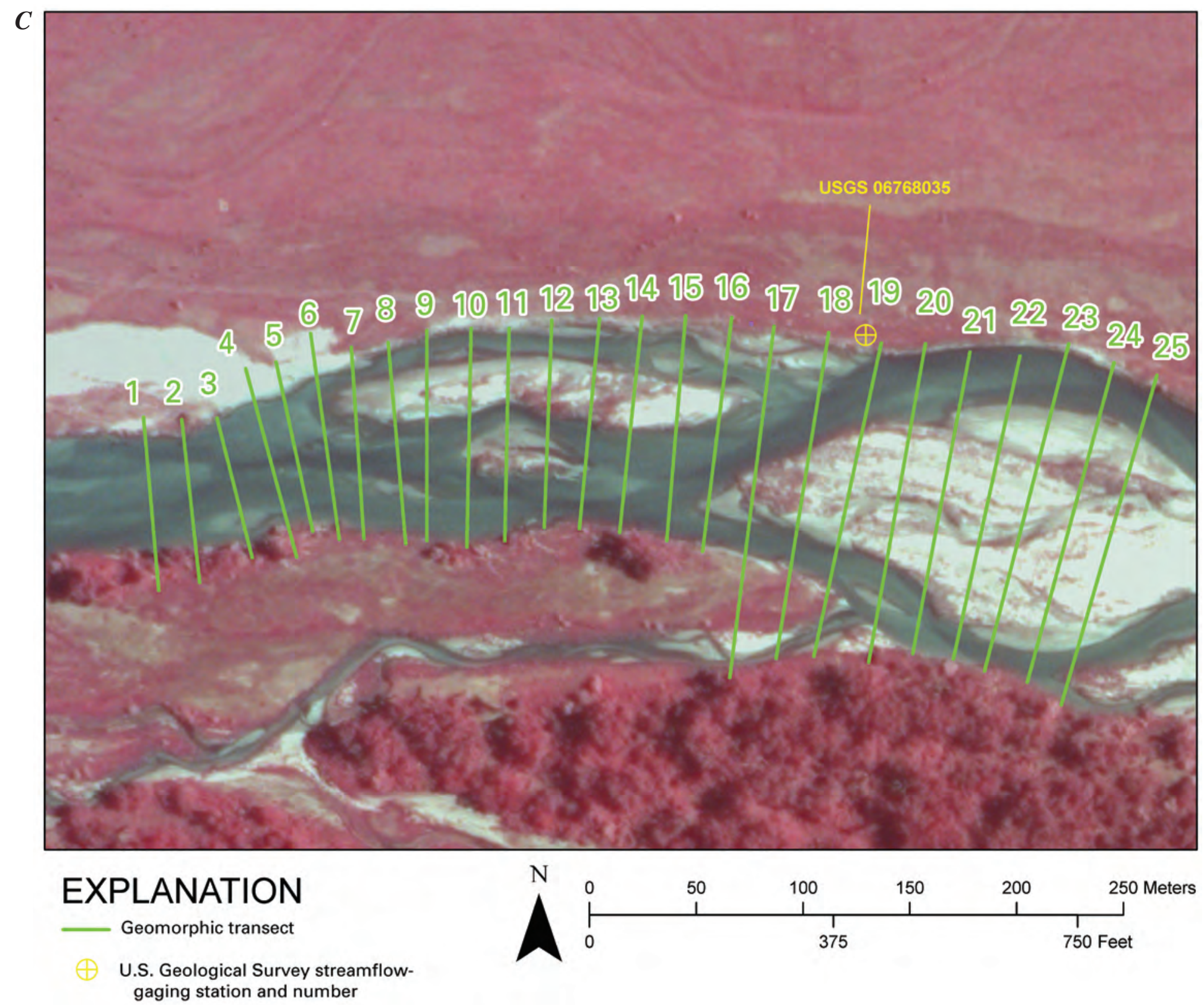

Figure 4-Continued. Aerial color infrared photograph of reaches in the Cottonwood Ranch study area taken June 22, 2008, showing the location of geomorphic monitoring transects. Flow is from left to right. $C$, Photograph of the Output Reach. This photograph also shows USGS streamflow-gaging station 06768035, Platte River Middle Channel at Cottonwood Ranch near Elm Creek, Nebr. 


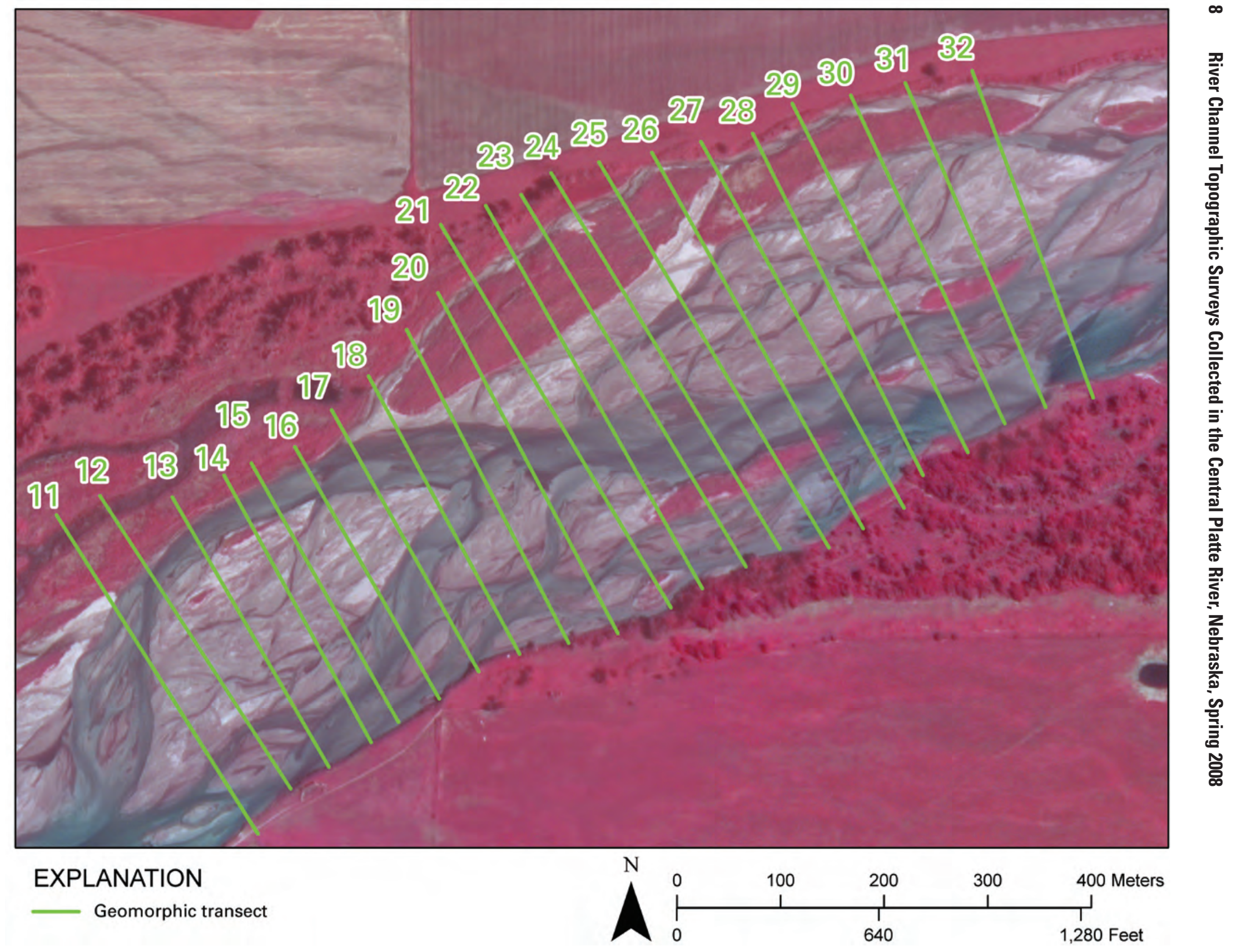

Figure 5. Aerial color infrared photograph of the Rowe Sanctuary study area taken June 22, 2008, showing the location of geomorphic monitoring transects. Flow is from lower left to upper right. 


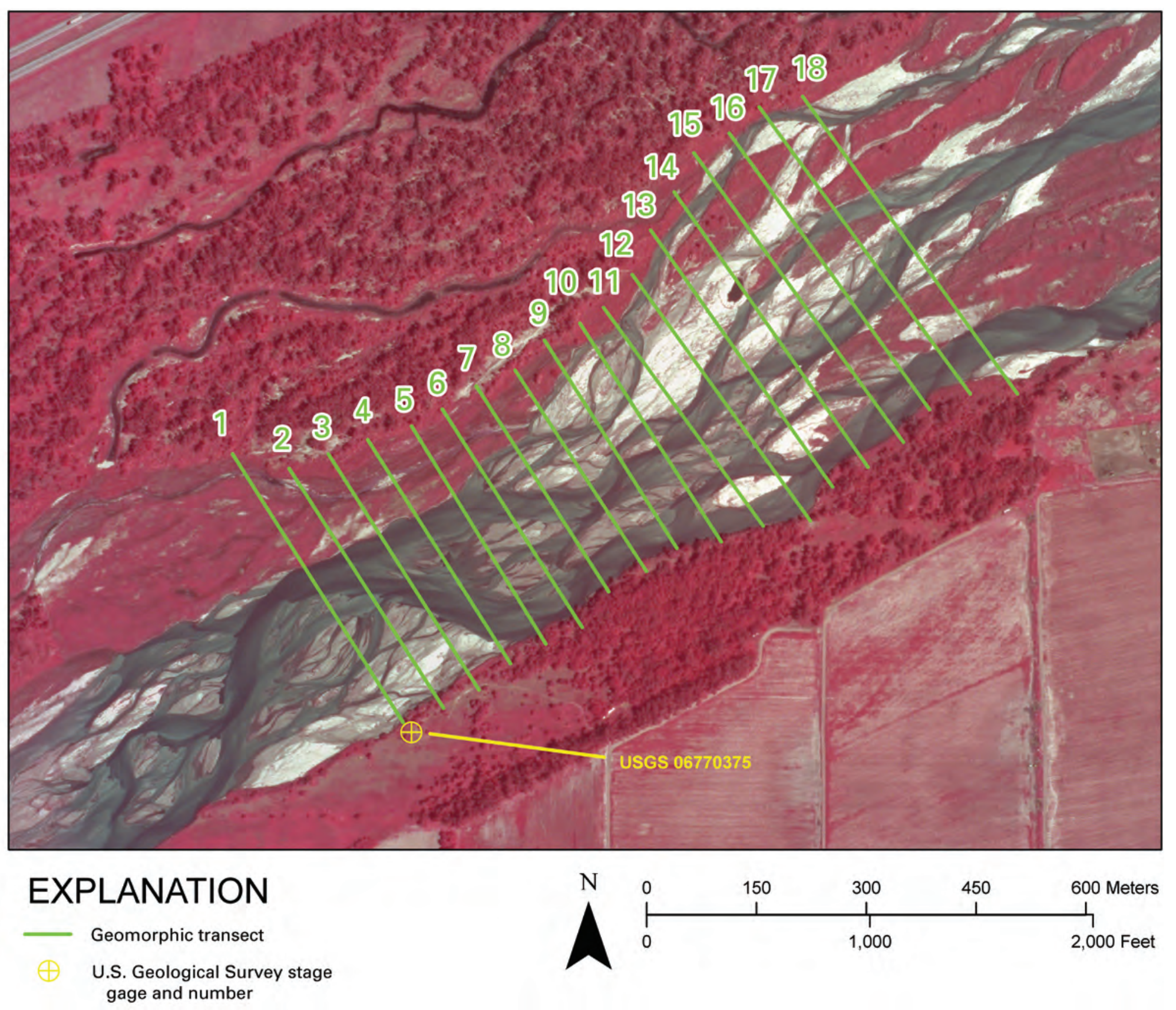

Figure 6. Aerial color infrared photograph of the Uridil study area taken June 22, 2008, showing the location of geomorphic monitoring transects and the USGS stage gage 06770375, Platte River near Prosser, Nebr. Flow is from lower left to upper right. 
Table 1. Topographic survey dates.

\begin{tabular}{ccc}
\hline \multicolumn{1}{c}{ Location } & \multicolumn{1}{c}{$\begin{array}{c}\text { Pre-event } \\
\text { survey }\end{array}$} & $\begin{array}{c}\text { Post-event } \\
\text { survey }\end{array}$ \\
\hline $\begin{array}{c}\text { Cottonwood Ranch } \\
\text { Input Reach }\end{array}$ & $3 / 11 / 08$ & $6 / 16 / 08$ \\
$\begin{array}{c}\text { Cottonwood Ranch } \\
\text { Managed Reach }\end{array}$ & $3 / 11 / 08$ & $6 / 16 / 08$ \\
Cottonwood Ranch & $3 / 10 / 08$ and 3/11/08 & $6 / 16 / 08$ \\
$\quad$ Output Reach & & \\
Rowe Sanctuary & $7 / 25 / 07$ and $7 / 26 / 07$ & $6 / 17 / 08$ \\
Uridil Property & $5 / 14 / 07$ and $5 / 15 / 07$ & $6 / 18 / 08$ \\
\hline
\end{tabular}

\section{Acknowledgments}

Assistance with field data collection was provided by Jason Alexander, Brent Hall, Brian Imig, and Matthew Moser (USGS, Lincoln, Nebr.), and Brandy Logan (USGS, Golden, Colo.). The streamflow-gaging stations in the central Platte are maintained by personnel in the USGS office in North Platte, Nebr. The author would like to thank the Nebraska Public Power District for allowing access to the Cottonwood Ranch Property, the National Audubon Society for allowing access to the Rowe Sanctuary, and the Platte River Whooping Crane Maintenance Trust for providing access to the Uridil Property. Sharon Gloe also gave permission to survey river transects located on her property adjacent to the Uridil Property.

\section{References Cited}

Johnson, W.C, 1997, Equilibrium response of riparian vegetation to flow regulation in the Platte River, Nebraska: Regulated Rivers-Research and Management, v. 13, p. 403-415.

Kinzel, P.J., Nelson, J.M., and Heckman, A.K., 2006, Channel morphology and bed sediment characteristics before and after riparian vegetation clearing in the Cottonwood Ranch, Platte River, Nebraska, water years 2001-2004: U.S. Geological Survey Scientific Investigations Report 2005-5285, 25 p., http://pubs.usgs.gov/sir/2005/5285/.

Kinzel, P.J., Nelson, J.M., and Heckman, A.K., 2008, Response of sandhill crane riverine roosting habitat to changes in stage and sandbar morphology: River Research and Applications, 18 p., http://www3.interscience.wiley.com/cgi-bin/ fulltext/119876487/PDFSTART/, 18 August 2008.

Kinzel, P.J., Wright, C.W., Nelson, J.M. and Burman, A.R., 2007, Evaluation of an experimental LiDAR for surveying a shallow, braided, sand-bedded river: Journal of Hydraulic Engineering, v. 133, no. 7, 838-842.

National Research Council, 2005, Endangered and threatened species of the Platte River: Washington, D.C., National Academies Press, 336 p.
Platte River Whooping Crane Maintenance Trust, 2003, Platte River least tern and piping plover sandbar nesting habitat restoration-Electronic grant application to Nebraska Environmental Trust: Wood River, Nebr., Platte River Whooping Crane Maintenance Trust, $52 \mathrm{p}$.

Smith, D.A., and Roman, D.R., 2001, GEOID99 and G99SSS-One arc-minute models for the United States: Journal of Geodesy, v. 75, p. 469-490.

Trimble Navigation Limited, 1998, Survey controller field guide. Version 7.0: Sunnyvale, Calif., Trimble Navigation Limited, 94 p.

U.S. Department of the Interior, 1997, Cooperative agreement for Platte River research and other efforts relating to endangered species habitats along the central Platte River, Nebraska: U.S. Department of the Interior, State of Nebraska, State of Wyoming, and State of Colorado.

U.S. Department of the Interior, 2006a, Platte River Recovery Implementation Program Cooperative Agreement: U.S. Department of the Interior, State of Nebraska, State of Wyoming, and State of Colorado, http://platteriverprogram.org/ Documents/PRRIP\%20Program\%20Agreement\%20Final.pdf, 19 August 2008.

U.S. Department of the Interior, 2006b, Platte River Recovery Implementation Program final environmental impact statement-Summary: U.S Department of Interior, prepared by Bureau of Reclamation and U.S. Fish and Wildlife Service, $92 \mathrm{p}$.

U.S. Geological Survey, 2008, Real-time data for Nebraska streamflow: U.S. Geological Survey National Water Information System, http://waterdata.usgs.gov/ne/nwis/ current/?type=flow, 18 August 2008.

Williams, G.P., 1978, The case of the shrinking channels-The North Platte and Platte Rivers in Nebraska: U.S. Geological Survey Circular 781, 48 p.

Publishing support provided by:

Denver Publishing Service Center, Denver, Colorado

Manuscript approved for publication, September 22, 2008

Edited by Melanie Parker

Graphics and layout by Joy Monson

For more information concerning this publication, contact:

Chief, Branch of Regional Research, Central Region

Box 25046, MS 418

Denver, C0 80225

(303) 236-5021

Or visit the USGS National Research Program Web site at: http://water.usgs.gov/nrp/

This publication is available online at:

http://pubs.usgs.gov/ds/380/ 
